\title{
Influencing Factors of Students' Smartphones Use for Academic Purposes: A Developing Country's Perspective
}

\author{
https://doi.org/10.3991/ijet.v16i23.26675 \\ Samuel Adu Gyamfi \\ Akenten Appiah-Menka University of Skills Training and Entrepreneurial Development, \\ Kumasi, Ghana \\ sagyamfieaamusted.edu.gh
}

\begin{abstract}
There is evidence that majority of students in many African countries own and use smartphones. Due to their portability and the many functions, they are used to perform, smartphones have virtually become a necessity. In education, it is known to facilitate communication and knowledge sharing among students. Yet, many students use smartphones for entertainment purposes. Worst of all, research that investigates the factors that influence students' use of smartphones for learning are scarce particularly, in many African countries. Therefore, this study examines the influencing factors of smartphone use for academic purposes. It deviates from the few existing studies that have predominantly drawn samples from tertiary students of developed countries. The study presented a research model founded on UTAUT 2. Responses were gathered from 708 Ghanaian high school students using a questionnaire. Based on these responses, Partial Least Square Structural Equation Modelling was used to validate the model. The results confirmed that Effort Expectancy, Facilitating Conditions and Social Influence have significant influence on Hedonic Motivation and Perceived Usefulness. Similarly, Habit and Price Value mediated the effects of Hedonic Motivation and Perceived Usefulness on Behavioural Intention and Use Behaviour. The findings suggest that, educational institutions must provide the necessary support conditions for students to use smartphones for learning.
\end{abstract}

Keywords—smartphone Use, academic purpose, learning, UTAUT 2

\section{Introduction}

\subsection{Background}

In recent years, the popularity of smartphones cannot be overemphasized. The world has virtually become a smartphone society. In the United Kingdom, 93\% of the population use smartphones [1]. Relevant research indicates that smartphone use in Africa doubled between 2014 and 2016 [2]. Indeed, more than 70\% of students in Turkey use smartphones [3]. They have become virtually a daily necessity where almost all activities depend on [4]. This is because, they possess the same capabilities as personal computers but with a bonus of mobility. Thus, the services enabled by these devices span 
across communication, commerce and entertainment [5]. In education, they are known to facilitate effective communication and collaboration among partners [6]. Given the wide penetration of smartphones even in developing countries, it is believed that smartphone use can complement the lack of adequate ICT infrastructure [7]. In effect, smartphones, have the potential to improve access of education particularly in rural areas and during pandemics. This is because, students will be able to access requisite learning materials and pool of informational resources that are needed for their development.

Despite the enormous potential of smartphones in education, they are seldom realized as an educational tool [5]. Many students perceive them as entertainment tools. Therefore, they rarely use them for learning. To add to this, research in this area is scarce, particularly in the African context. Existing studies have mostly explored students' use of generalized Information and Communication Technologies (ICTs) [8], [9] and social media for learning [10], [11] often drawing samples from university students. To be specific, the use of ICTs by high school students has been relegated to the background. [12] calls for the use of ICTs for promoting quality education to be equitable across the educational levels. Therefore, this paper adopts the Unified Theory of Acceptance and Use of Technology 2 (UTAUT 2) to investigate the factors that affect high school students' use of smartphones for academic purposes. The findings discovered in this research will inform relevant stakeholders about the various interventions needed to enhance the adoption of smartphone use for academic purposes. Relevant literature is reviewed in the next section. This is followed by a presentation of theoretical framework and hypothesis formulation. The methods and data analysis techniques are presented before discussions and conclusions are drawn.

\section{$2 \quad$ Related literature}

Education is a major concern particularly in the developing world. Over the years, many stakeholders have set up various initiatives for improving the quality of education in these areas. Arguably, the most popular of all, is the United Nation's Sustainable Development Goal Four (SDG4). The objective of SDG4 is to ensure inclusive and equitable quality education and promote lifelong learning opportunities for all. This is an enhancement of the Millennium Development Goals which focused on the realization of universal primary education [13]. The SDG4 focuses on the provision of opportunities for the transformation of young learners into global knowledge creators and sharers.

Among others, ICTs have been regarded as a key resource for achieving these educational outcomes. ICTs have been recognized to provide equal learning opportunities for learners across the world [14]. This does not only apply to the increased access to curriculum and relevant information but also strengthening of educational relationships for collaboration and knowledge sharing [15]. According to [16], ICTs enable different categories of students to learn at their own pace. Similarly, complex concepts are easily demonstrated and dissected using ICTs [17]. Yet, its use for learning in many African 
countries has been somewhat lukewarm. Studies have attributed this to the lack of adequate ICT infrastructure in schools [12], [18], [19]. In other studies, lack of teacher readiness for ICT integration in education has been highlighted as the main challenge [20], [21], [22]. Thus, many of the studies that make these assumptions examined teacher competences and school level ICT infrastructure in terms of the availability of computer laboratories, personal computers and internet facilities. However, ICTs span across different devices. Smartphones in recent years are among the predominately used ICT tools [4]. Out of 1,940 Ghanaian students, [23] found that 99.5\% owned and used smartphones. Although, smartphones are not allowed in many African schools, students are allowed to use them at home. Yet, they rarely use these devices for educational purposes.

Outcome of [24]'s study, concluded that students mostly use smartphones for social activities. In a different study, [25] found that interacting on social media is the main activity conducted using smartphones. In Africa, relevant studies agree that these devices are mainly used for entertainment rather than educational purposes [19]. [23] indicates that compared to academic activities, social and leisure activities such as listening to music and watching videos were the prevalent activities performed by students. Consequently,[10] conceive that many African students do not perceive these tools as learning tools. Other scholars have also speculated that the cost of and inadequate internet infrastructure have been a major barrier for ICTs use for learning. However, these studies are not specific to smartphones. Consequently, in this study the factors that inform the use of smartphone for academic purpose are investigated.

\section{Theoretical foundation}

A number of technology acceptance theories have been extensively explored in information systems research. Perhaps, the popular ones are the Technology Acceptance Model (TAM) [26] and Unified Theory of Acceptance and Use of Technology (UTAUT) [27]. TAM proposes that users form intention to use a technology before actual usage. However, these intentions are informed by their perceptions of its usefulness and ease of use. UTAUT is an improvement of TAM. It argues that Performance Expectancy, Effort Expectancy, Social Influence and Facilitating Conditions predict Behavioural Intention to use a technology. Meanwhile, Behaviour Intentions and Facilitating conditions directly influence Use Behaviour. Although, UTAUT has been widely adopted in many information systems research, the theoretical model explains a relatively low variance for behavioural intention (56\%) and actual use (40\%) [28]. Unified Theory of Acceptance and Use of Technology 2 (UTAUT 2) is an extension of the original UTAUT. It incorporates three additional constructs: Habit, Price Value and Hedonic Motivation. The extension enabled improvements in the variances of behavioural intentions (52\%) and actual use (74\%) [28]. This suggests that UTAUT 2 is more useful than the earlier theories discussed hence, UTAUT 2 is adopted for this study. Although studies have sought to extend the theory with relevant constructs, very few have examined the relationship among its constructs. Thus, in an attempt to discover the influencing factors of smartphone use for academic purposes, the inter-relationship 
among the various constructs in UTAUT 2 is examined. In effect, the study investigates the relationship between Performance Expectancy, Effort Expectancy, Social Influence, Facilitating Conditions, Habit, Price Value and their effect on students' Behavioural Intention to use smartphones for academic purposes. Further, the relationship between Behavioural Intention and Use Behaviour of smartphones for academic purposes is examined. Table 1 presents a summary of definitions for the constructs in the context of this study and their sources in literature.

Table 1. Construct definitions and sources

\begin{tabular}{|l|l|c|}
\hline \multicolumn{1}{|c|}{ Construct } & \multicolumn{1}{|c|}{ Definition } & Source \\
\hline $\begin{array}{l}\text { Performance Ex- } \\
\text { pectancy (PE) }\end{array}$ & $\begin{array}{l}\text { The degree to which students believe that mobile internet technologies (e.g., } \\
\text { smartphone) use will help them attain gains in academic tasks. }\end{array}$ & {$[29],[30]$} \\
\hline $\begin{array}{l}\text { Effort Expec- } \\
\text { tancy (EE) }\end{array}$ & $\begin{array}{l}\text { The degree of ease associated with the use of mobile internet technologies } \\
\text { (e.g., smartphone) for academic activities. }\end{array}$ & {$[27],[29]$} \\
\hline $\begin{array}{l}\text { Social Influence } \\
\text { (SI) }\end{array}$ & $\begin{array}{l}\text { The extent to which students believe that it is important to think they should } \\
\text { use mobile internet technologies (e.g., smartphone) for academic activities }\end{array}$ & {$[30,[27]$} \\
\hline $\begin{array}{l}\text { Facilitating Con- } \\
\text { ditions (FC) }\end{array}$ & $\begin{array}{l}\text { The extent of availability of technical support for using mobile internet tech- } \\
\text { nologies (e.g., smartphone) for learning. }\end{array}$ & {$[31],[29]$} \\
\hline $\begin{array}{l}\text { Hedonic Motiva- } \\
\text { tion (HM) }\end{array}$ & $\begin{array}{l}\text { The enjoyment or pleasure resulting from mobile internet technologies (e.g. } \\
\text { smartphone) use for academic activities. }\end{array}$ & {$[29],[32]$} \\
\hline Habit (H) & $\begin{array}{l}\text { It refers to automating behaviour from initial learning to regular use of mo- } \\
\text { bile internet technologies (e.g., smartphone) for academic work. }\end{array}$ & {$[32],[30]$} \\
\hline Price Value (PV) & $\begin{array}{l}\text { It is students' cognitive trade- off between perceived benefits and monetary } \\
\text { cost for mobile internet technologies (e.g., smartphone) use for academic } \\
\text { work. }\end{array}$ & {$[29],[31]$} \\
\hline $\begin{array}{l}\text { Behavioural In- } \\
\text { tention (BI) }\end{array}$ & $\begin{array}{l}\text { Refers to students' intentions to use mobile internet technologies (e.g., } \\
\text { smartphone) for academic activities in the near future. }\end{array}$ & {$[29],[30]$} \\
\hline $\begin{array}{l}\text { Use Behaviour } \\
\text { (UB) }\end{array}$ & $\begin{array}{l}\text { The extent to which students' actually use mobile internet technologies (e.g., } \\
\text { smartphone) for academic work. }\end{array}$ & {$[29]$} \\
\hline
\end{tabular}

\subsection{Hypotheses Formulation}

Effort Expectancy (EE), Facilitating Conditions (FC) and Hedonic Motivation (HM). Effort Expectancy (EE) explains the degree of ease associated with mobile internet technology (e.g., smartphones) use for learning [29]. [29] argues that technology behaviour is highly dependent on the level of effort required for system use. Thus, systems that are difficult to use often leave users dissatisfied and restless. Conversely, users find pleasure and enjoyment with technologies that are easy to use [31]. Similarly, when the required conditions that facilitate system use exist, users will be satisfied. Facilitating Conditions is the belief that the necessary infrastructure and support are available for system use [27]. That is, students will enjoy using smartphones for learning when they perceive that the adequate support required are available. With this background, it is proposed that:

- H1: Effort Expectancy (EE) positively affects Hedonic Motivation (HE).

- H2a: Facilitating Conditions (FC) positively affects Hedonic Motivation (HE). 
Facilitating Conditions (FC), Social Influence (SI) and Performance Expectancy (PE). As explained earlier, Facilitating Conditions (FC) entail the availability of required infrastructure and support for using mobile internet technology (e.g., smartphones) for academic purposes [29]. In line with [32], people positively value systems when the needed infrastructure is available. Students will view smartphones as useful for academic purposes when they get the needed support for its use for learning. Moreover, perceptions of respected others influence students' behaviour towards smartphones [27]. In other words, when students believe that people important to them perceive smartphones as useful for academic work, they will be more likely to use them for such purposes. Therefore, it is proposed that:

- H2b: Facilitating Conditions (FC) positively affects Performance Expectancy (PE).

- H3: Social Influence (SI) positively affects Performance Expectancy (PE)

Hedonic Motivation (HM), Performance Expectancy (PE), Habit (H) and Price Value (PV). According to [29], Hedonic Motivation (HM) is encapsulated in the enjoyment or happiness as a result of using a technology. Intrinsic utilities such as joy and pleasure students may receive as a result of using smartphones affect their perceptions [30]. For instance, when students enjoy using smartphones for academic purposes, it is likely they will perceive it as useful. Similarly, when students possess positive perceptions about smartphone use and academic activities, they are increasingly motivated to regularly use them. Moreover, perceptions of system usefulness influence the perceptions of accrued benefits [32]. In other words, when smartphones are believed to be effective for academic work, students are likely to perceive greater benefits. Hence, it is argued that:

- H4a: Hedonic Motivation (HM) positively affects Performance Expectancy (PE).

- H4b: Hedonic Motivation (HM) positively affects Habit (H).

- H5a: Performance Expectancy (PE) positively affects Habit $(\mathrm{H})$.

- H5b: Performance Expectancy (PE) positively affects Price Value (PV).

Habit (H), Price Value (PV) and Behavioural Intentions (BI). Habit is the belief that a behaviour is automatic as a result of learning [29]. It may infer students' experiences with regards to using smartphones for academic work [31]. In addition, users often compare the benefits associated with technology use and the cost that maybe incurred. To put differently, when there is a higher perception of Price Value, students will be more enthused to use smartphones for academic work [29]. This is to suggest that, students must perceive the advantages enabled by smartphones for learning to be greater than the monetary cost associated with its use. Indeed, many studies have found Habit and Price Value to significantly influence Behavioural Intention [31], [32]. As a result, it is concluded that:

- H6: Habit (H) positively affect Behavioural Intentions (BI).

- H7: Price Value (PV) positively affect Behavioural Intentions (BI)

Behavioural Intentions and Use Behaviour. Extant studies have proposed a significant positive relationship between Behavioural Intention and Use Behaviour [33], 
[27]. Different studies have provided evidence that users are likely to use a technology once intentions are formed [32], [31]. Thus, students' use of mobile internet technologies (e.g., smartphones) for learning is largely predicted by their willingness to adopt. Meanwhile, [34] argues that, intentions do not always predict behaviour. Therefore, in an attempt to verify the relationship between Behavioural Intention and Use Behaviour, it is suggested that:

- H8: Behavioural Intention (BI) positively affect Use Behaviour (UB).

In figure 1 the various constructs that form the research model and how they have been predicted to affect each other are represented.

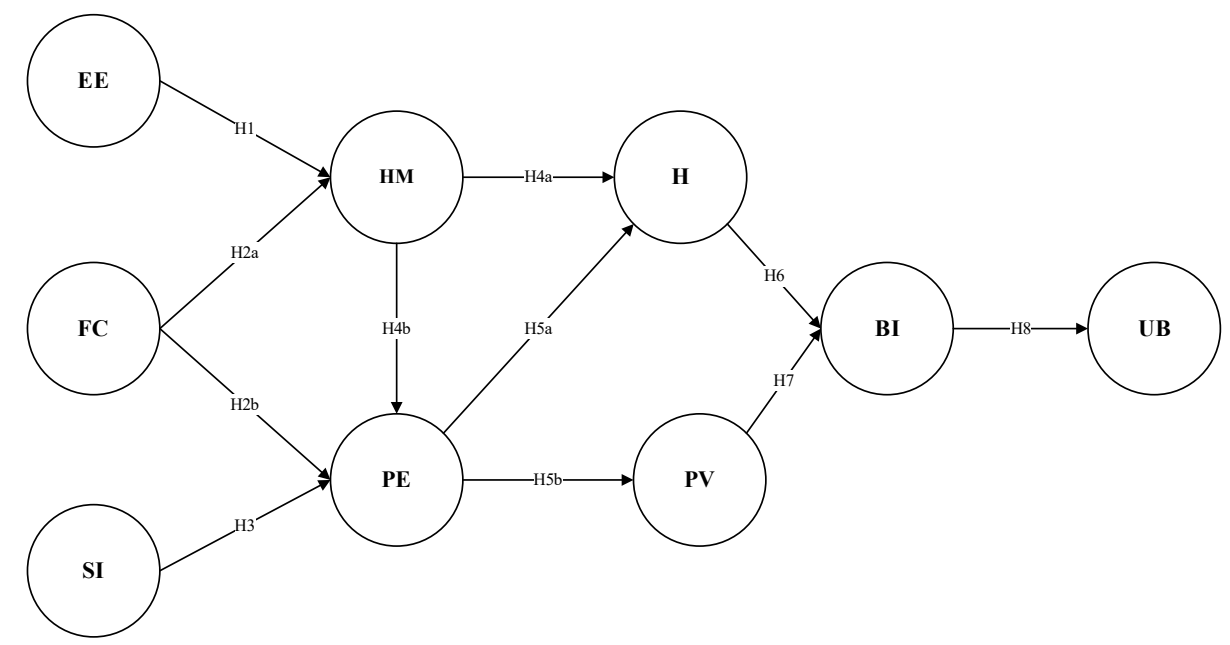

Fig. 1. Research model

\section{Research method}

A survey questionnaire was designed to explore the relationship between the constructs in the research model. Respondents' opinions on (i) Performance Expectancy (ii) Effort Expectancy (iii) Social Influence (iv) Facilitating Conditions (v) Habit (vi) Price Value (vii) Behavioural Intentions and (viii) Use Behaviour were gathered. All constructs had at least three question items that were modified from prior studies (see Table 1). All question items were reflective and ranged from strongly agree (7) to Strongly Disagree (1). In order to be concise, only relevant demographic information was included in the questionnaire. This was also to ensure confidentiality and anonymity. Whereas respondents were conveniently sampled, participation was purely voluntary. 


\subsection{Data collection}

The data collection period lasted for about a month. The questionnaire was administered to 800 high school students in Ghana. However, 735 responses were received. Out of this total 27 responses were incomplete hence discarded. Therefore, 708 responses were valid for analysis. Male respondents formed $59 \%$ of the final sample with the remaining $41 \%$ been female. The mean age was 17 years. Majority (44\%) were in second year, $34 \%$ were in third year and 22 were in their first year. The summary of respondents' demographics is presented in Table 2.

Table 2. Respondents' Demographics

\begin{tabular}{|l|c|c|c|}
\hline \multicolumn{1}{|c|}{ Demographics } & Value & Frequency & Percentage \\
\hline \multirow{3}{*}{ Sex } & Male & 418 & $59 \%$ \\
\cline { 2 - 4 } & Female & 290 & $41 \%$ \\
\hline \multirow{3}{*}{ Age } & $11-13$ & 162 & $23 \%$ \\
\cline { 2 - 4 } & $14-15$ & 489 & $69 \%$ \\
\cline { 2 - 4 } & Above 15 & 57 & $8 \%$ \\
\hline \multirow{3}{*}{ Education Level } & 1st Year & 156 & $22 \%$ \\
\cline { 2 - 4 } & 2nd Year & 311 & $44 \%$ \\
\cline { 2 - 4 } & 3rd Year & 241 & $34 \%$ \\
\hline
\end{tabular}

\section{Data analysis}

Partial Least Square Structural Equation Modelling (PLS-SEM) was adopted to estimate the research model. This approach was suitable because, it is robust to multivariate distribution errors [35]. Again, PLS-SEM offer potent techniques for assessing the measurement and structural model. Hence, it enables researchers to rigorously measure the relationship among latent variables [36]. With PLS-SEM, the effects of independent variables can be easily predicted. Consequently, PLS-SEM software SmartPLS 3.0 was used for the analysis.

\subsection{Measurement model}

The measurement model assesses the validity and reliability of the variables and question items adopted for the study. [36] specifically recommend that the measurement model is evaluated with regards to item reliability, internal consistency, convergent validity, discriminant validity and the possibility of collinearity. All question item loadings met [37]'s recommended threshold of 0.7. Moreover, the traditional Cronbach's Alpha as well as composite reliability were implemented to evaluate internal consistency. Table 3 indicates that both measures were above [38]'s preferred minimum of 0.7. Also, [39] preferred convergent validity assessment with Average Variance Extracted (AVE) was chosen. The author allows a minimum AVE value of 0.5. Table 3 presents the summary of the AVE values for the constructs. 
Table 3. Construct Reliability and Validity

\begin{tabular}{|l|c|c|c|c|}
\hline & Cronbach's Alpha & rho_A & Composite Reliability & Average Variance Extracted (AVE) \\
\hline BI & 0.890 & 0.729 & 0.726 & 0.501 \\
\hline EE & 0.714 & 0.741 & 0.839 & 0.635 \\
\hline FC & 0.848 & 0.850 & 0.770 & 0.530 \\
\hline H & 0.763 & 0.868 & 0.863 & 0.678 \\
\hline HM & 0.781 & 0.781 & 0.859 & 0.604 \\
\hline PE & 0.986 & 0.888 & 0.827 & 0.615 \\
\hline PV & 0.742 & 0.804 & 0.781 & 0.562 \\
\hline SI & 0.754 & 0.776 & 0.858 & 0.670 \\
\hline UB & 0.992 & 0.915 & 0.829 & 0.708 \\
\hline
\end{tabular}

Discriminant validity was measured using [40]'s criteria. Thus, the square root of AVEs of latent variables were juxtaposed with correlations among other latent variables. The author recommends that the square root of AVE of a latent variable should be greater than all other latent variables. The highlighted diagonal entries in Table 4 indicate that this criterion was met.

Table 4. Discriminant Validity

\begin{tabular}{|l|c|c|c|c|c|c|c|c|c|}
\hline & BI & EE & FC & H & HM & PE & PV & SI & UB \\
\hline BI & $\mathbf{0 . 7 0 8}$ & & & & & & & & \\
\hline EE & 0.704 & $\mathbf{0 . 7 9 7}$ & & & & & & & \\
\hline FC & 0.638 & 0.600 & $\mathbf{0 . 7 2 8}$ & & & & & & \\
\hline H & 0.553 & 0.533 & 0.558 & $\mathbf{0 . 8 2 4}$ & & & & & \\
\hline HM & 0.586 & 0.575 & 0.625 & 0.692 & $\mathbf{0 . 7 7 7}$ & & & & \\
\hline PE & 0.532 & 0.506 & 0.539 & 0.679 & 0.728 & $\mathbf{0 . 7 8 4}$ & & & \\
\hline PV & 0.399 & 0.327 & 0.423 & 0.402 & 0.433 & 0.429 & $\mathbf{0 . 7 5 0}$ & & \\
\hline SI & 0.596 & 0.558 & 0.531 & 0.656 & 0.693 & 0.671 & 0.466 & $\mathbf{0 . 8 1 9}$ & \\
\hline UB & 0.564 & 0.496 & 0.536 & 0.697 & 0.663 & 0.691 & 0.421 & 0.653 & $\mathbf{0 . 8 4 1}$ \\
\hline
\end{tabular}

Finally, the possibility of collinearity was examined using the Variance Inflation Factor (VIF) [41] values lesser than 3. Table 5 presents VIF values for constructs

Table 5. Variance Inflation Factor Validity

\begin{tabular}{|l|c|c|c|c|c|c|}
\hline & BI & H & HM & PE & PV & UB \\
\hline BI & & & & & & 1.000 \\
\hline EE & & & 1.563 & & & \\
\hline FC & & & 1.563 & 1.692 & & \\
\hline H & 1.193 & & & & & \\
\hline HM & & 2.125 & & 2.336 & & \\
\hline PE & & 2.125 & & & 1.000 & \\
\hline PV & 1.193 & & & & & \\
\hline SI & & & & 1.982 & & \\
\hline
\end{tabular}




\subsection{Structural model}

The Bootstrap technique (100 sample) as recommended by [42] when the sample size is greater than 100 was employed to analyse the structural model. The model explained $34.3 \%$ and $31.8 \%$ of the variances in Behavioural Intent and Use Behaviour respectively. Moreover, it also explained variances for Hedonic Motivation (45.3\%), Performance Expectancy (58.7\%), Habit (54.4\%), and Price Value (18.4\%). The relationship among the constructs were explored using path coefficients. Path coefficient $(\beta)$ is significant when $p$-value is less than 0.05 .

\section{$6 \quad$ Results}

From the loadings, all predicted relationships were supported. Specifically, Facilitating Conditions $(\beta=0.90, p<0.05)$, Hedonic Motivation $(\beta=0.461, p<0.001)$ and Social Influence $(\beta=0.303, p<0.001)$ had significant influence on Performance Expectancy. Meanwhile, Facilitating Conditions $(\beta=0.438, \mathrm{p}<0.001)$ and Effort Expectancy $(\beta=0.312, p<0.001)$ predicted Hedonic Motivation. Furthermore, whereas Performance Expectancy $(\beta=0.372, p<0.001)$ and Hedonic Motivation $(\beta=0.422, p<$ $0.001)$ positively affected Habit, Performance Expectancy $(\beta=-0.429, \mathrm{p}<0.001)$ had a negative relationship with Price Value. Accordingly, while Habit $(\beta=0.469, \mathrm{p}<$ $0.001)$ positively affected Behavioural Intentions, Price Value had a negative influence $(\beta=-0.210, p<0.001)$. Behavioural Intentions $(\beta=0.564, \mathrm{p}<0.001)$ also had a positive association with Use Behaviour. Finally, the effects sizes of these relationships were assessed using [43]'s criteria. According to [43], effect size (f 2) are irrelevant (i.e. f 2 $<0.02$ ), small (f $2 \geq 0.02$ ), medium (f $2 \geq 0.15$ ) or large (f $2 \geq 0.35$ ). The summary of the path coefficients and effect sizes are presented in Table 6 .

Table 6. Significance of Path Coefficients

\begin{tabular}{|c|c|c|c|c|c|c|}
\hline & $\begin{array}{c}\text { Original } \\
\text { Sample }(0)\end{array}$ & $\begin{array}{c}\text { Sample } \\
\text { Mean (M) }\end{array}$ & $\begin{array}{c}\text { Standard Deviation } \\
\text { (STDEV) }\end{array}$ & $\begin{array}{l}\text { T Statistics } \\
(|\mathrm{O} / \mathrm{STDEV}|)\end{array}$ & P Values & Effect Sizes $\left(\mathbf{f}^{\mathbf{2}}\right)$ \\
\hline BI $->$ UB & 0.564 & 0.567 & 0.041 & 13.605 & 0.000 & 0.467 \\
\hline $\mathrm{EE}->\mathrm{HM}$ & 0.312 & 0.319 & 0.053 & 5.926 & 0.000 & 0.114 \\
\hline $\mathrm{FC}->\mathrm{HM}$ & 0.438 & 0.436 & 0.056 & 7.867 & 0.000 & 0.224 \\
\hline $\mathrm{FC}->\mathrm{PE}$ & 0.090 & 0.091 & 0.049 & 1.850 & 0.032 & 0.012 \\
\hline $\mathrm{H}->\mathrm{BI}$ & 0.469 & 0.471 & 0.055 & 8.503 & 0.000 & 0.281 \\
\hline $\mathrm{HM}->\mathrm{H}$ & 0.422 & 0.423 & 0.062 & 6.850 & 0.000 & 0.184 \\
\hline $\mathrm{HM}->$ PE & 0.461 & 0.462 & 0.057 & 8.077 & 0.000 & 0.221 \\
\hline $\mathrm{PE}->\mathrm{H}$ & 0.372 & 0.371 & 0.059 & 6.276 & 0.000 & 0.143 \\
\hline PE -> PV & 0.429 & 0.435 & 0.047 & 9.159 & 0.000 & 0.226 \\
\hline $\mathrm{PV}->\mathrm{BI}$ & 0.210 & 0.215 & 0.056 & 3.737 & 0.000 & 0.057 \\
\hline SI -> PE & 0.303 & 0.305 & 0.066 & 4.595 & 0.000 & 0.113 \\
\hline
\end{tabular}

In figure 2, a graphical representation of the structural model is presented. The figures on the arrows indicate the significance of path coefficients. 


\section{Discussion}

The study adopted the UTAUT 2 model to examine the influencing factors of students' smartphone use for academic purposes. In an attempt to augment relevant literature, the chapter examined the relationships among the constructs of the UTAUT 2. First of all, the study verified that UTAUT 2 is an effective framework for assessing technology behaviour. Indeed, the research model explained $34.3 \%$ and $31.8 \%$ of the variances in Behaviour Intention and Use Behaviour respectfully. In addition, all proposed relationships were significant. First of all, user perceptions of smartphone use for academic purposes as well as pleasure of usage is informed by the availability of essential support, perceptions of relevant others and the level of ease for using smartphones.

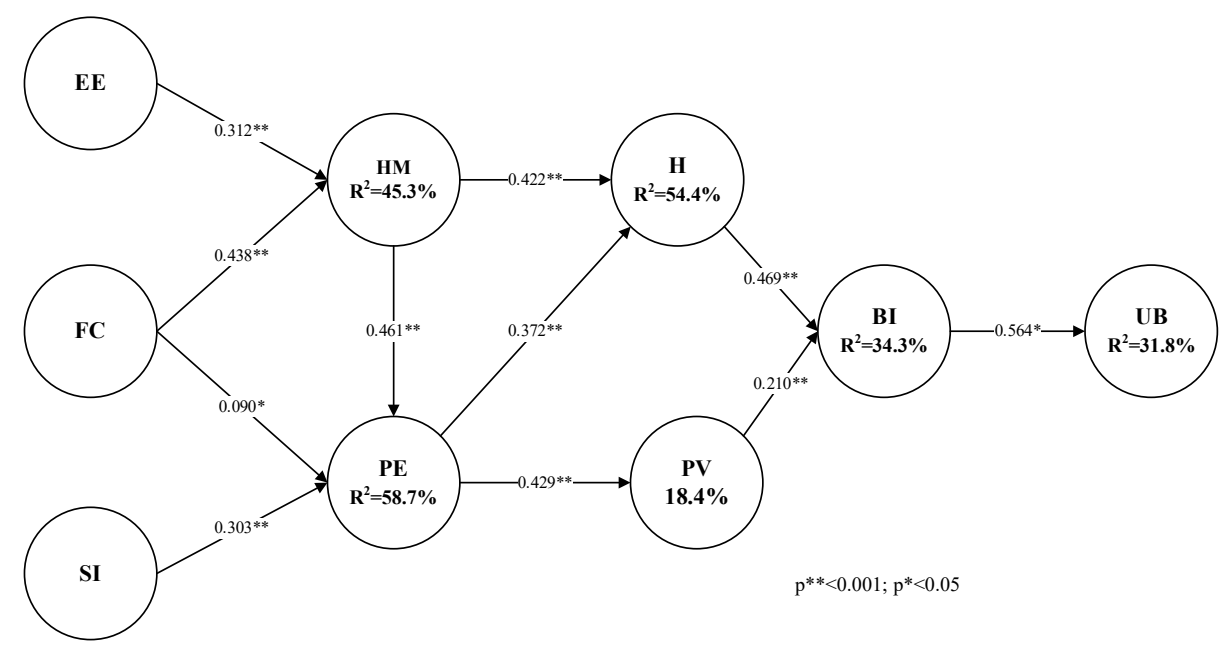

Fig. 2. Structural model

This is congruent with [44] and [45]. Therefore, institutions that seek to encourage smartphone usage for academic purposes must be concerned with increasing required support and perception of usefulness of smartphones. One way to increase usefulness perception is by educating students about effective ways to use smartphones for academic work in order to reap desired benefits. In turn, this will enlighten their perceptions about smartphone usage as well as reduce the difficulty during use. It was also recorded that Hedonic Motivation and Performance Expectancy significantly affect Habit and Price Value [46]. Hence, it is expected that once students enjoy using smartphone for academic work, they will use them regularly. Finally, this increases their willingness to use and consequently, their actual usage of smartphones for learning. However, institutions must note that students will not enjoy or use smartphones regularly until required infrastructure and support such as reliable internet facilities are available. 
Paper-Influencing Factors of Students' Smartphones Use for Academic Purposes: A Developing...

\section{Conclusion}

Smartphone use has been prevalent recently. Evidence indicates that students use them ubiquitously for many activities. Studies have shown that, affordances enabled by these devices give hope on quality education because they enable equal access of learning opportunities for all. Nonetheless, they are rarely used for academic purposes. This has led researchers to conclude that smartphones are predominantly perceived as entertainment rather than educational tools [47]. Yet, studies that investigate smartphone usage for academic work is scarce particularly, in Africa. In this study, the relationships among the constructs of the UTAUT 2 model is modified to examine the influencing factors of smartphone use for academic work. The final finding indicated that Effort Expectancy, Facilitating Condition and Social Influence affect Perceived Usefulness and Hedonic motivation. However, Habit and Price mediated the effect of Perceived Usefulness and Hedonic motivation on Behavioural Intention. Finally, User Behaviour was influenced by Behavioural Intention. From the results institutions and teachers are encouraged to raise awareness through educative programmes on smartphone usage for education. However, the adoption of convenience sampling technique limits the study. Perhaps, future works could model with a random sample. It will also be interesting if the model is explored in rural and urban students' context.

\section{References}

[1] D. Kuss, L. Harkin, E. Kanjo and J. Billieux, "Problematic Smartphone Use: Investigating Contemporary Experiences Using a Convergent Design," International Journal of Environmental Research and Public Health, vol. 15, no. 1, p. 142, 2018. https://doi.org/10.3390/ ijerph15010142

[2] A. L. Dahir, "Smartphone use has doubled in Africa in two years," Quartz Media, Inc., 3 August 2016. [Online]. Available: https://qz.com/africa/748354/smartphone-use-has-morethan-doubled-in-africa-in-two-years/. [Accessed 10 August 2021]. https://doi.org/10.1787/ $\underline{888933202403}$

[3] K. Demirci, M. Akgönül and A. Akpinar, "Relationship of Smartphone Use Severity with Sleep Quality, Depression and Anxiety in University Students," Journal of Behavioural Addictions, vol. 4, no. 2, pp. 85-92, 2015. https://doi.org/10.1556/2006.4.2015.010

[4] A. Z. Wali, and M. E. Omaid, "The Use of Smartphones as an Educational Tool in the Classroom: Lecturers' Perceptions," International Journal of Emerging Technologies in Learning (IJET), vol. 15, no. 16, pp. 238-247, 2020. https://doi.org/10.3991/ijet.v15i16.14179

[5] A. Razzaq, Y. T. Samiha, and M. Anshari, "Smartphone Habits and Behaviors in Supporting Students Self-Efficacy," International Journal of Emerging Technologies in Learning (IJET), vol. 13, no. 02, pp. 94-109, 2018. https://doi.org/10.3991/ijet.v13i02.7685

[6] D. Wakgari and B. P. Ramesh, "The Role of Effective Integration of ICT in Education, especially in Primary and Secondary Education of Remote Settings," International Journal of Advanced Research in Computer Science, vol. 8, no. 9, pp. 10-13, 2017.

[7] T. Songu, A. Powell, B. Barry and P. P. Brar, "Improving Quality Education and Research Capacity through Advanced ICT Lessons: Lessons of NREN implementation in Sierra Leone," in 9th UbuntuNet Alliance Annual Conference, 2016, Entebbe, 2016. 
Paper-Influencing Factors of Students' Smartphones Use for Academic Purposes: A Developing...

[8] F. W. K. Amenyedzi, M. N. Lartey and B. M. Dzomeku, "The Use of Computers and Internet as Supplementary Source of Educational Material: A Case Study of the Senior High Schools in the Tema Metropolis in Ghana," Contemporary Education Technology, vol. 2, no. 2, pp. 151-162, 2011. https://doi.org/10.30935/cedtech/6049

[9] V. Arkorful and N. Abaidoo, "The Role of E-learning, Advantages and Disadvantages of its Adoption in Higher Education," International Journal of Instructional Technology and Distance Learning, vol. 12, no. 1, pp. 29-42, 2015.

[10] F. N. Koranteng, I. Wiafe and E. Kuada, "An Empirical Study of the Relationship between Social Networking Sites and Students' Engagement in Higher Education," Journal of Educational Computing Research, vol. 57, no. 5, pp. 1131-1159, 2019. https://doi.org/ $10.1177 / 0735633118787528$

[11] F. N. Koranteng and I. Wiafe, "Factors that Promote Knowledge Sharing on Academic Social Networking Sites: An Empirical Study," Education and Information Technologies, vol. 24, no. 2, pp. 1211-1236, 2019. https://doi.org/10.1007/s10639-018-9825-0

[12] S. Samarakoon, A. Christiansen and P. G. Munro, "Equitable and Quality Education for All of Africa? The Challenges of Using ICT in Education," Perspectives on Global Development and Technology, vol. 16, no. 6, pp. 645-665, 2017. https://doi.org/10.1163/1569149712341454

[13] S. Fukuda-Parr, "From the Millennium Development Goals to the Sustainable Development Goals: Shifts in Purpose, Concept, and Politics of Global Goal Setting for Development," Gender \& Development, vol. 24, no. 1, pp. 43-52, 2016. https://doi.org/10.1080/13552074. $\underline{2016.1145895}$

[14] M. Turner-Cmuchal and A. Stuart, "ICT as a Tool for Supporting Inclusive Learning Opportunities," Implementing Inclusive Education: Issues in Bridging the Policy-Practice Gap, vol. 8, pp. 159-180, 2016. https://doi.org/10.1108/s1479-363620160000008010

[15] F. N. Koranteng, F. K. Sarsah, E. Kuada and S. A. Gyamfi, "An Empirical Investigation into the Perceived Effectiveness of Collaboarative Software for Students' Projects," Education and Information Technologies, vol. 25, no. 2, pp. 1085-1108, 2020. https://doi.org/10. 1007/s10639-019-10011-7

[16] E. Reddy, B. Sharma, P. Reddy and M. Dakuidreketi, "Mobile Learning Readiness and ICT Competency: A Case Study of Senior Secondary School Students in the Pacific Islands," in 2017 4th Asia-Pacific World Congress on Computer Science and Engineering (APWC on CSE), Mana Island, Fiji, 2017. https://doi.org/10.1109/apwconcse.2017.00031

[17] A. T. Grigg, Evaluating the effect of the digital divide between teachers and students on the meaningful use of information and communication technology in the classroom, Edith Cowan University, 2016.

[18] N. M. Mndzebele, N. D. Mzomba and C. B. S. Mndebele, "Determinants of ICT Integration in Teaching Secondary School Agriculture: Experience of Southern Africa (Swaziland)," in Proceedings of the International Conference on Information Technology \& Systems (ICITS 2018), 2018. https://doi.org/10.1007/978-3-319-73450-7_91

[19] C. Buabeng-Andoh and I. Yidana, "Teachers' ICT Usage in Second-Cycle Institutions in Ghana: A Qualitative Study," International Journal of Education and Development Using ICT, vol. 11, no. 2, 2015.

[20] V. Msila, "Teacher Readiness and Information and Communications Technology (ICT) Use in Classrooms: A South African Case Study.," Creative Education, vol. 06, pp. 1973-1981, 2015. https://doi.org/10.4236/ce.2015.618202

[21] P. Basargekar and C. Singhavi, "Factors Affecting Teachers' Perceived Proficiency in Using ICT in the Classroom," IAFOR Journal of Education, vol. 5, no. 2, pp. 67-84, 2017. https://doi.org/10.22492/ije.5.2.03 
Paper-Influencing Factors of Students' Smartphones Use for Academic Purposes: A Developing...

[22] R. Debra and A. A. Qua-Enoo, "ICT Usage in Senior High School Education in Ghana: Effects of Demographic Antecedents," International Journal of Computing, vol. 7, no. 6, pp. 68-86, 2018.

[23] F. S. Mensah, "Ghanaian Tertiary Students' use of ICT," Global Journal of Human-Social Science Research, vol. 17, no. 3, pp. 13-18, 2017.

[24] F. D. Alosaimi, H. Alyahya, H. Alshahwan, N. Al Mahyijari and S. A. Shaik, "Smartphone addiction among university students in Riyadh, Saudi Arabia," Saudi Medical Journal, vol. 37, no. 6, pp. 675-683, 2018. https://doi.org/10.15537/smj.2016.6.14430

[25] H. Lee, H. Ahn, T. G. Nguyen, S. W. Choi and D. J. Kim, "Comparing the Self-Report and Measured Smartphone Usage of College Students: A Pilot Study," Psychiatry Investigation, vol. 14, no. 2, pp. 198-204, 2017. https://doi.org/10.4306/pi.2017.14.2.198

[26] F. D. Davis, "Perceived Usefulness, Perceived Ease of Use, and User Acceptance of Information Technology.," MIS Quarterly, vol. 13, no. 3, pp. 319-340, 1986. https://doi.org/ $10.2307 / 249008$

[27] V. Venkatesh, M. Morris, G. Davis and F. Davis, "User Acceptance of Information Technology: Toward a Unified View," MIS Quarterly, vol. 27, no. 3, pp. 425-478, 2003. https://doi.org/10.2307/30036540

[28] A. Chang, "UTAUT and UTAUT 2: A Review and Agenda for Future Research," The Winners, vol. 13, no. 2, pp. 106-114, 2012. https://doi.org/10.21512/tw.v13i2.656

[29] V. Venkatesh, J. Thong and X. Xu, "Consumer Acceptance and Use of Information Technology: Extending the Unified Theory of Acceptance and Use of Technology," MIS Quarterly, vol. 36, no. 1, pp. 157-178, 2012. https://doi.org/10.2307/41410412

[30] A. A. Alalwan, Y. K. Dwivedi and N. P. Rana, "Factors influencing adoption of mobile banking by Jordanian bank customers: Extending UTAUT2 with trust," International Journal of Information Management, vol. 37, no. 3, pp. 99-110, 2017. https://doi.org/ 10.1016/j.ijinfomgt.2017.01.002

[31] A. Raman and Y. Don, "Preservice Teachers' Acceptance of Learning Management Software: An Application of the UTAUT2 Model," International Education Studies, vol. 6, no. 7, pp. 157-164, 2013. https://doi.org/10.5539/ies.v6n7p157

[32] A. A. Alalwan, Y. K. Dwivedi, N. P. Rana and R. Algharabat, "Examining factors influencing Jordanian customers' intentions and adoption of internet banking: Extending UTAUT2 with risk," Journal of Retailing and Consumer Services, vol. 40, pp. 125-138, 2018. https://doi.org/10.1016/i.jretconser.2017.08.026

[33] S. Brown and V. Venkatesh, "Model of Adoption of Technology in Households: A Baseline Model Test and Extension Incorporating Household Life Cycle," MIS Quarterly, vol. 29, no. 3, pp. 399-426, 2005. https://doi.org/10.2307/25148690

[34] I. Wiafe, K. Nakata and S. Gulliver, "Categorizing users in behavior change support systems based on cognitive dissonance," Personal Ubiquitous Computing, vol. 18, p. 1677-1687, 2014. https://doi.org/10.1007/s00779-014-0782-3

[35] D. Gefen, E. Rigdon and D. Straub, "Editor's Comments: An Update and Extension to SEM Guidelines for Administrative and Social Science Research," MIS Quarterly, vol. 35, no. 2, pp. iii-xiv, 2011. https://doi.org/10.2307/23044042

[36] J. F. Hair, J. J. Risher, M. Sarstedt and C. M. Ringle, "When to Use and How to Report the Results of PLS-SEM," European Business Review, vol. 31, no. 1, pp. 2-24, 2019. https://doi. org/10.1108/ebr-11-2018-0203

[37] D. Barclay, C. Higgins and R. Thompson, "The Partial Least Squares (PLS) Approach to Causal Modeling: Personal Computer Use as an Illustration," Technology Studies, vol. 2, no. 2, pp. 285-309, 1995. 
Paper-Influencing Factors of Students' Smartphones Use for Academic Purposes: A Developing...

[38] R. P. Bagozzi and Y. Yi, "On the evaluation of structural equation models," Journal of the Academy of Marketing Science, vol. 16, p. 74-94, 1988.

[39] B. H. Wixom and H. J. Watson, "An Empirical Investigation of the Factors Affecting Data Warehousing Success,” MIS Quarterly, vol. 25, no. 1, pp. 17-41, 2001. https://doi.org/ $10.2307 / 3250957$

[40] C. Fornell and D. F. Larcker, "Evaluating Structural Equation Models with Unobservable Variables and Measurement Error," Journal of Marketing Research, vol. 18, no. 1, pp. 3950, 1981. https://doi.org/10.1177/002224378101800104

[41] J. F. Hair, Jr., G. T. M. Hult, C. M. Ringle and M. Sarstedt, A Primer on Partial Least Squares Structural Equation Modeling (PLS-SEM), 3rd ed., SAGE Publications, 2021. https://doi.org/10.3926/oss.37

[42] N. Kock, "Using WarpPLS in E-collaboration Studies: An Overview of Five Main Analysis Steps," International Journal of e-Collaboration, vol. 6, no. 4, pp. 1-11, 2010. https://doi.org/ 10.4018/978-1-61350-459-8.ch011

[43] J. Cohen, Statistical Power Analysis for the Behavioural Sciences, 2nd Revised ed., New York: Lawrence Erlbaum Associates, 2013.

[44] L. F. Rodrigues, A. Oliveira and J. C. Carlos, "Does ease-of-use contributes to the perception of enjoyment? A case of gamification in e-banking," Computers in Human Behavior, vol. 61, pp. 114-126, 2016. https://doi.org/10.1016/j.chb.2016.03.015

[45] H. van der Heijden, "User Acceptance of Hedonic Information Systems," MIS Quarterly, vol. 28, no. 4, pp. 695-704, 2004. https://doi.org/10.2307/25148660

[46] S. Yang, "Understanding Undergraduate Students' Adoption of Mobile Learning Model: A Perspective of the Extended UTAUT2," Journal of Convergence Information Technology, vol. 8, no. 10, pp. 969-979, 2013. https://doi.org/10.4156/jcit.vol8.issue10.118

[47] X. Shen and J. L. Wang, "Loneliness and excessive smartphone use among Chinese college students: Moderated mediation effect of perceived stressed and motivation," Computers in Human Behavior, vol. 95, pp. 31-36, 2019. https://doi.org/10.1016/j.chb.2019.01.012

[48] J. Cohen, Statistical Power Analysis for the Behavioural Sciences, 2nd revised ed., New York: Lawrence Erlbaum Associates, 2013.

\section{Author}

Samuel Adu Gyamfi is with Akenten Appiah-Menka University of Skills Training and Entrepreneurial Development, Department of Information Technology Education, Kumasi, Ghana.

Article submitted 2021-09-01. Resubmitted 2021-10-25. Final acceptance 2021-10-26. Final version published as submitted by the author. 